\title{
Liquid Chromatography Single Quadrupole Mass Spectrometry (LC/SQ MS) Analysis Reveals Presence of Novel Antineoplastic Metabolites in Ethanolic Extracts of Fruits and Leaves of Annona
}

\section{muricata}

\author{
Yahaya Gavamukulya ${ }^{1,2, *}$, Esther N Maina ${ }^{1,3}$, Amos M Meroka ${ }^{3,4}$, Edwin S Madivoli ${ }^{1,5}$, Hany A El-Shemy ${ }^{1,6}$, \\ Gabriel Magoma', Fred Wamunyokoli ${ }^{1,7}$
}

Yahaya Gavamukulya ${ }^{1,2, *}$, Esther

N Maina ${ }^{1,3}$, Amos Meroka ${ }^{3,4}$,

Edwin S Madivoli ${ }^{1,5}$, Hany A El-

Shemy ${ }^{1,6}$, Gabriel Magoma', Fred

Wamunyokoli ${ }^{1,7}$

'Department of Molecular Biology and Biotechnology, Pan African University Institute for Basic Sciences, Technology and Innovation (PAUSTI), P. O. Box, 62000-00200 Nairobi, KENYA. 2Department of Biochemistry and Molecular Biology, Faculty of Health Sciences, Busitema University, P.O. Box, 1460 Mbale, UGANDA.

${ }^{3}$ Department of Biochemistry, College of Health Sciences, University of Nairobi, P.O. Box 3019700100 Nairobi, KENYA.

${ }^{4}$ Department of Biochemistry, School of

Medicine and Health Sciences, Kenya Methodist University, P.O. Box 267-60200 Meru, KENYA. ${ }^{5}$ Department of Chemistry, College of Pure and Applied Sciences, Jomo Kenyatta University of Agriculture and Technology, P. O. Box, 6200000200 Nairobi, KENYA.

${ }^{6}$ Department of Biochemistry, Faculty of Agriculture, Cairo University, 12613 Giza, EGYPT. 'Department of Biochemistry, College of Health Sciences, Jomo Kenyatta University of Agriculture and Technology, P. O. Box, 6200000200 Nairobi, KENYA.

\section{Correspondence}

Yahaya Gavamukulya

Department of Molecular Biology and Biotechnology, Pan African University Institute for Basic Sciences, Technology and Innovation (PAUSTI), P. O. Box, 6200000200, Nairobi, KENYA

Tel. +256775869783

E-mail: gavayahya@yahoo.com

History

- Submission Date: 18-11-2018;

- Review completed: 08-04-2019;

- Accepted Date: 15-04-2019.

\section{DOI : 10.5530/pj.2019.11.104}

Article Available online

http://www.phcogj.com/v11/i4

Copyright

(C) 2019 Phcogj.Com. This is an openaccess article distributed under the terms of the Creative Commons Attribution 4.0 International license.

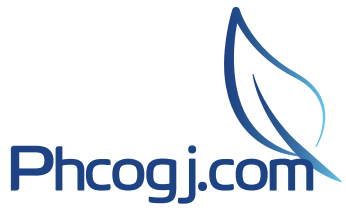

\begin{abstract}
Background: Annona muricata, a tropical plant species belonging to family Annonaceae is one of the most used plants in folk medicine because of its many medicinal uses. Despite its wide usage, there is still need to continue scientifically evaluating its medicinal properties in order to avoid any adverse effects. Elucidating the detailed chemical composition of this plant is a significant step towards this evaluation. Objective: The aim of this study was to conduct LC MS analysis on the ethanolic extracts of fruits and leaves of Annona muricata for detection of novel metabolites. Materials and Methods: Leaves and fruits of Annona muricata were collected from Eastern Uganda during the month January 2018. Extraction was conducted using the tissue homogenization method and the extracts were analyzed on an LC/SO MS detection system. The results were obtained by analyzing the MS spectra using the retentions time and fragmentation patterns on the NIST Library. Results: The study revealed that the fruits extracts contain 1,3-Dimethylthiourea and (4-chlorophenyl)-[4-(3-chlorophenyl)-2-[(Z)-3-(dimethylamino) prop-1-enyl]quinolin-6-yl]-(3-methylimidazol-4-yl)methanol, which are reported antioxidant and antineoplastic agents. The leaves contained 2,4,6-Tribromoaniline another antioxidant and antineoplastic agent, while compound (dichlorozirconium(2+);dimethyl-bis(2-methyl-4phenylinden-1-id-1-yl)silane was found in both extracts of fruits and leaves. Conclusion: The current study suggests that ethanolic extracts of fruits and leaves of Annona muricata contain compounds which are potent antioxidant, antineoplastic and therapeutic agents for various conditions and paves the way for the development of several treatment regimens from these plant parts. Finally, the compounds reported in this study have been identified for the first time as being found in Annona muricata.
\end{abstract}

Key words: Annona muricata, Ethanolic extracts, Phytochemicals, LC/SQ MS, Antioxidant, Antineoplastic.

\section{INTRODUCTION}

There is a global increase in the use of medicinal plants for health reasons. In developing countries, herbal drugs and traditional remedies are relatively more popular, because of cultural acceptability and belief that being natural, they are safe and nontoxic. Although, there are some new approaches to drug discovery, such as combinatorial chemistry and computer based molecular modeling design, none of them can replace the importance of natural products in drug discovery and development. ${ }^{1-3}$ Annona muricata L. is a species of the Annonaceae family that has been widely studied in the last decades due to its therapeutic potential. Annona muricata is known as Soursop (English), Graviola (Portuguese), Guanábana (Latin American Spanish), Omusitafeli / Ekitafeli (Uganda) and other local indigenous names as has been enlisted. ${ }^{4,5}$ This plant is a species of the genus Annona with the following taxonomic classification. Kingdom:
Plantae, Division: Angiosperms (Magnoliophyta), Class: Magnolids, Order: Magnoliales, Family: Annonaceae, Genus: Annona, Species : Annona muricata $L .^{6}$ The Annona muricata tree is about 5-10 $\mathrm{m}$ tall and $15-83 \mathrm{~cm}$ in diameter with low branches. $^{7-9}$ It is widely distributed in the tropical regions of Central and South America, Western Africa, Central and Eastern Africa and Southeast Asia ${ }^{3,6}$ at altitudes below $1200 \mathrm{~m}$ above sea level, with temperatures between 25 and $28^{\circ} \mathrm{C}$, relative humidity between 60 and $80 \%$ and annual rainfall above 1500 $\mathrm{mm}$. The fruit is an edible collective ovoid berry, dark green in color.

Various medicinal uses have been reported across the globe ranging from the use of leaves, bark, roots, fruits and seeds of Annona muricata. ${ }^{10}$ The most widely used preparation in traditional medicine is the decoction of bark, root, seed or leaf but applications are varied. Ethnobotanical studies have indicated that Annona muricata has been used as insecticide ${ }^{11}$ and parasiticide. ${ }^{12}$ Fruit juice and infusions of leaves

Cite this article: Gavamukulya Y, Maina EN, Meroka A, Madivoli ES, El-Shemy HA, Magoma G, et al. Liquid Chromatography Single Quadrupole Mass Spectrometry (LC/SO MS) Analysis Reveals Presence of Novel Antineoplastic Metabolites in Ethanolic Extracts of Fruits and Leaves of Annona muricata. Pharmacog J. 2019;11(4):660-8. 
or branches have been used to treat fever, ${ }^{13,14}$ sedative, ${ }^{15,16}$ respiratory illness, ${ }^{17-19}$ malaria, ${ }^{20-24}$ gastrointestinal problems, ${ }^{14,25,26}$ liver, heart and kidney affections. ${ }^{10,27}$ In recent years it has become widely used for hypoglycemic, ${ }^{28}$ hypotensive $e^{26,28,29}$ and cancer. ${ }^{13,23,30-37}$

A number of publications and reviews about Annona muricata have been conducted to integrate the available scientific studies on this plant with special interest on acetogenins as principal bioactive compounds. ${ }^{4,6,10,38}$ In terms of composition, the predominant compounds in Annona muricata are acetogenins followed by alkaloids, phenols and other compounds. ${ }^{39,40}$ Additionally, preliminary phytochemical screening conducted on ethanolic extracts of leaves of Annona muricata have been reported to reveal the presence of alkaloids, flavonoids, terpenoids, coumarins and lactones, anthraquinones, tannins, cardiac glycosides, phenols, phytosterols and saponins being present with noticeable differences in relative abundance of all ranging from low, average and high. ${ }^{33}$ These reports notwithstanding, studies aimed at elucidating the chemical composition of Annona muricata ethanolic extracts from Eastern Uganda have identified only a few of the many recognized compounds. GC MS analysis done in East Africa on ethanolic extracts of leaves were reported to identify 12 of the 25 detected compounds. ${ }^{3}$ This leaves room to use higher resolution analyses for identification of more of the chemical compounds from the ethanolic extracts of fruits and leaves of Annona muricata from this region in order to effectively make good use of the plant's medicinal potential. LC MS analysis has been pointed out as one of the higher resolution analytical techniques which can be used to identify many unidentified compounds of natural origin. A literature search of the previous studies did not reveal any work on LC MS analysis of extracts of Annona muricata from the current geographical region of Eastern Africa, similarly, very little had been reported from the rest of the world regions. The aim of this study was therefore to conduct a phytochemical study of the ethanolic extracts of fruits and leaves of Annona muricata using LC MS analysis so as to elucidate more about the secondary metabolites in these parts of the plant.

\section{MATERIALS AND METHODS}

\section{Samples collection and authentication}

Fresh leaves and ripe fruits of Annona muricata were collected from the wild in Eastern Uganda in the districts of Kaliro, Iganga and Mbale during the month of January 2018. The plant was identified and authenticated in the Makerere University Botanical Herbarium (MHU) by Dr Namaganda Mary and a voucher specimen was deposited in the herbarium with the accession number MHU50860. The study was registered by the Uganda National Council for Science and Technology (Reg no: NS 43ES).

\section{Samples preparation and extraction}

The Fruits of Annona muricata were washed with clean water and then peeled to remove the fresh pulp. The pulp was then cut into small pieces and placed in a hot air oven to dry at $50^{\circ} \mathrm{C}$ for a week. The dried pulp was then milled into a powder using an electric grater. $100 \mathrm{~g}$ of powdered fruits were extracted using $250 \mathrm{ml}$ of absolute ethanol for three days by the plant tissue homogenization method as previously described. ${ }^{33}$ The Ethanolic Extracts of Annona muricata fruits (EEAM-Fruits) was then concentrated using a rotary evaporator to reduce on the amount of the extraction solvent and then kept at $4^{\circ} \mathrm{C}$ until use.

The leaves of Annona muricata were washed with water and cut into small pieces, drying was done at room temperature and the dried leaves were powdered. $100 \mathrm{~g}$ of powdered leaves were extracted using 250 $\mathrm{ml}$ absolute ethanol for three days by the plant tissue homogenization method as previously described. ${ }^{33}$ The Ethanolic Extracts of Annona muricata leaves (EEAM-Leaves) was then concentrated using a rotary evaporator to reduce on the amount of the extraction solvent and then and kept at $4^{\circ} \mathrm{C}$ until use.

\section{Chemicals and reagents}

All chemicals and reagents were procured from Zayo-Sigma, a certified supplier for Sigma-Aldrich in Uganda and were of the highest analytical standard.

\section{Liquid chromatography single quadrupole mass spectroscopy}

\section{Sample preparation for LCMS}

$10 \mu$ of each of the concentrated samples (EEAM-Leaves and EEAMFruits) were diluted 100 fold using methanol, which was to be used as the part of the mobile phase. The diluents were ultra-filtered with Whatman membrane filters nylon pore size $0.2 \mu \mathrm{m}$ (Sigma-Aldrich) and then kept at $4^{\circ} \mathrm{C}$ until run on the LCMS.

\section{LC MS parameters for secondary phytochemical analysis}

\section{Liquid chromatography (LC) parameters}

A Liquid Chromatography system utilizing PerkinElmer Brownlee ${ }^{\mathrm{TM}}$ Hres $\mathrm{C} 18$ column $(2.1 \mathrm{~mm} \times 50 \mathrm{~mm}, 1.9 \mu \mathrm{m})$ was used. The mobile phase program, run in isocratic mode, comprised of methanol: water mixture (75\%:25\% ratio) in formic acid (10 mM ammonium formate, $\mathrm{pH} 3$ ) system. ${ }^{41}$ The sample injection volume was $5 \mu \mathrm{l}$ and set at a flow rate of $0.2 \mathrm{ml} / \mathrm{min}$ and the total run time was $10 \mathrm{mins}$. Column temperature and heat block temperature were $40^{\circ} \mathrm{C}$ while the dissolution line temperature was $250^{\circ} \mathrm{C}$. High purity Nitrogen gas (99.99\%) was used as both nebulizing and drying gas. The drying gas flow rate was $10 \mathrm{~L} / \mathrm{min}$, interface voltage was $4.5 \mathrm{kv}$ and the interface current was $5.3 \mathrm{uA}$. The elution form LC columns was directed to the MS.

\section{Single quadrupole mass spectrometer (SQ MS) parameters}

A PerkinElmer Flexar ${ }^{\text {ix }}$ SQ 300 MS Ultra High Definition Single Quadrupole Mass Spectrometer detector using a Chromera ${ }^{\circ}$ Chromatography Data System, Chromera Version 3.4.4.5945 was utilized for the analysis. High definition mass spectrometry was performed on a single Quadrupole Mass system detector and operated in Electrospray Ionization (ESI) positive (resolution mode) to enable detection of secondary metabolite compounds. ${ }^{41}$ The mass spectrometer was operated in extended dynamic range with a scan mass range of $50-1000 \mathrm{~m} / \mathrm{z}$ and spectra saved in the MS for further identification. The elution to the MS was after every $4 \mathrm{~min}$. MS retention time and fragmentation patterns were used for identification of the compounds through scanning the National Institute of Standards and Technology (NIST) Library. Multiple optimizations and scans were done to reduce on the background noise and come up with the best baseline stabilizations for accurate compound identifications. MS spectra, TIC and identified compounds with their corresponding structures were retrieved from the Library as well as the PubChem Compounds database.

\section{RESULTS AND DISCUSSION}

\section{LC/SQ MS analysis of the ethanolic extracts of the fruits}

LC-MS analysis of the ethanolic extracts of fruits of Annona muricata generated three peaks with the retention times of $0.5475,5.6422$, $7.12391 \mathrm{~min}$ (Figures 1, 2, and 3). Each peak was then fragmented, resulting 12, 9 and 7 fragmentation spectra as shown in Figures 1,2 and 3 respectively. The LC MS spectra interpretation was performed using the NIST Library and corresponding compounds identified. The results of spectrum interpretation on ethanolic extracts of fruits of Annona muricata indicates that there are three detected substances. The names, structures and uses have been elucidated as shown Table 1. 


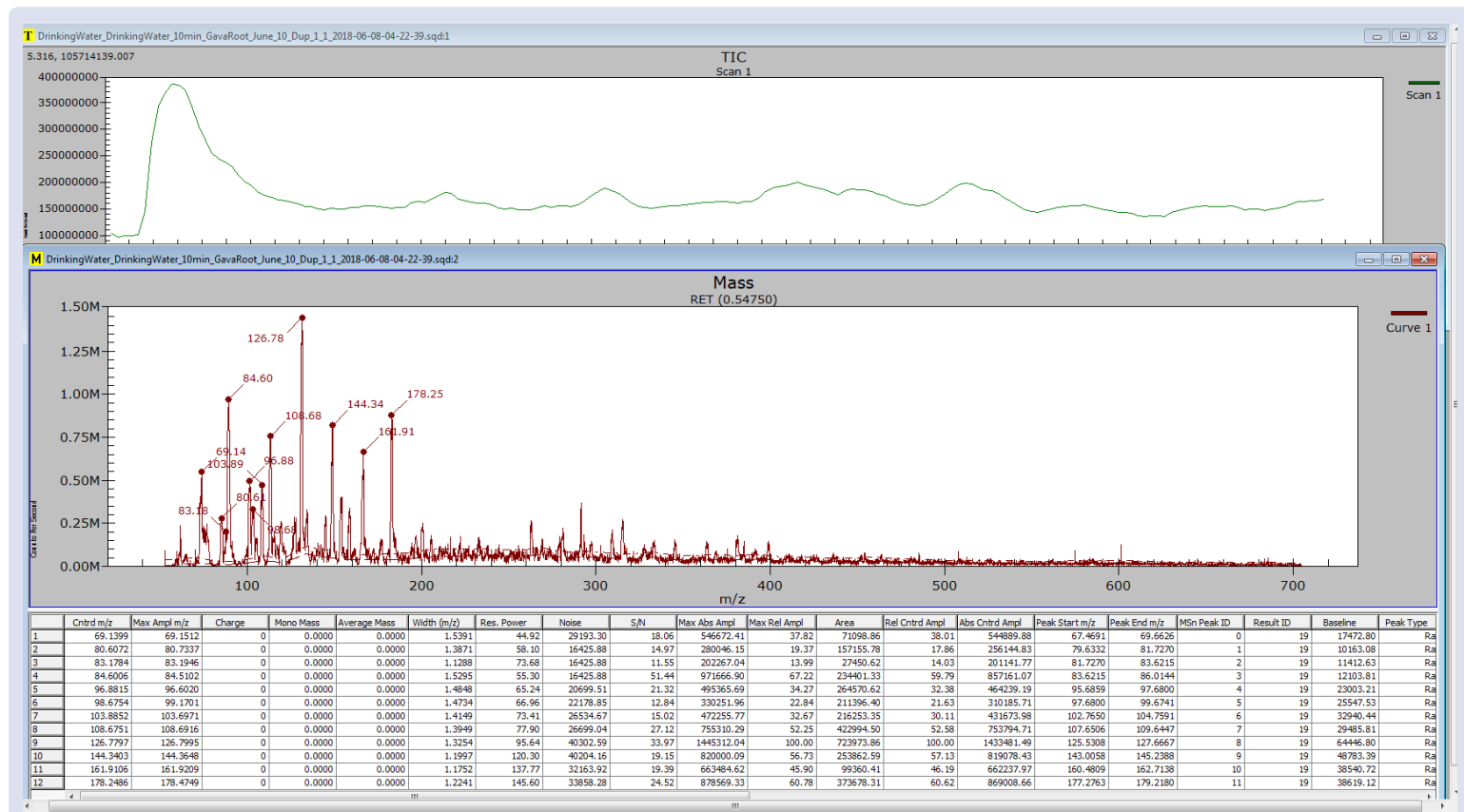

Figure 1: LC MS total ion chromatogram for EEAM- fruits at peak 1.

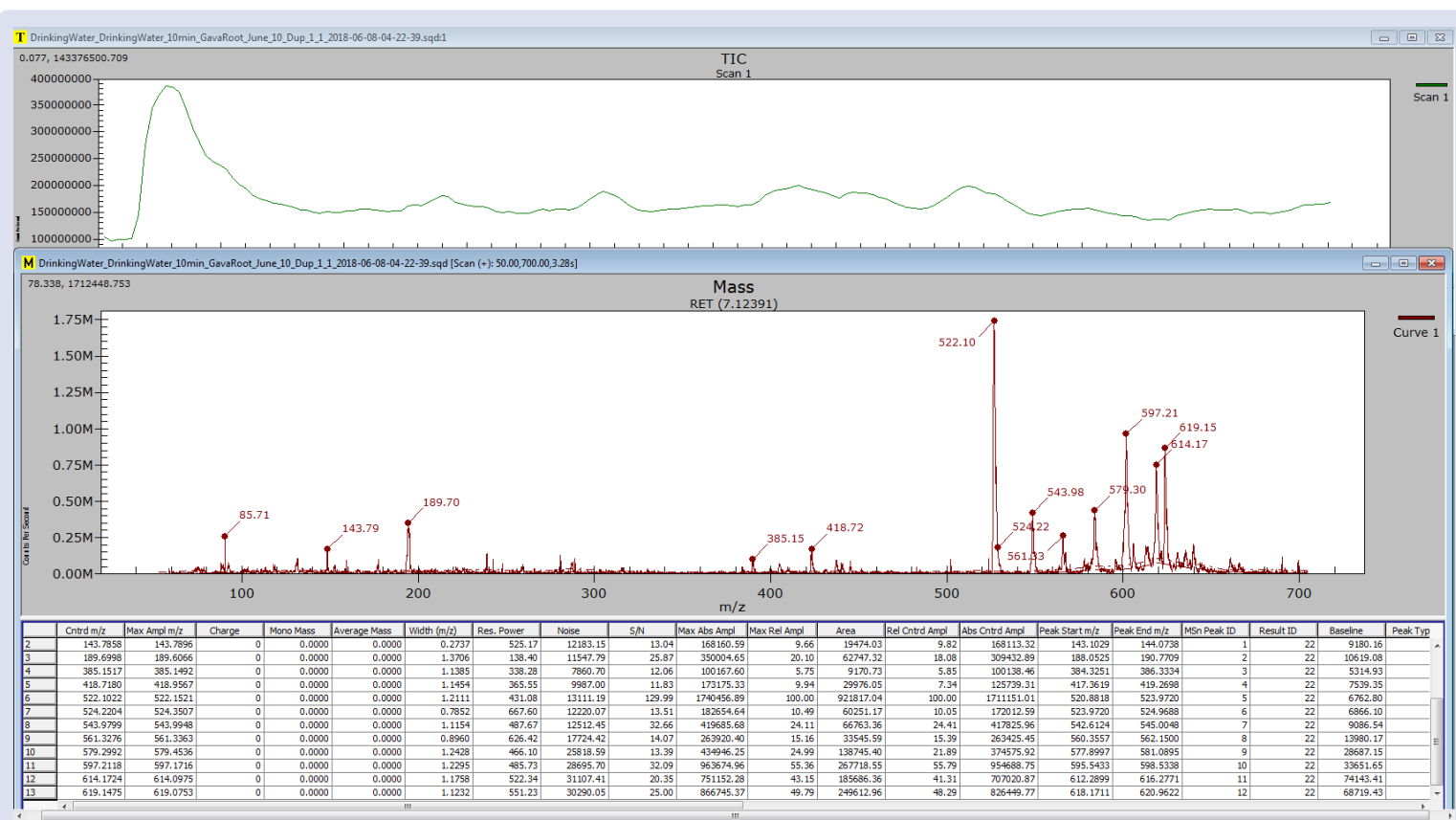

Figure 2: LC MS total ion chromatogram for EEAM- fruits at peak 2.

The first peak was fragmented into 12 spectra with candidate mass $(\mathrm{m} / \mathrm{z}) 69.14,80.61,83.18,84.60,96.88,98.68,103.89,108.68,126.78$, 144.34, 161.91 and 178.25 as shown in Figure 1 above. The LC MS spectrums interpretation was performed using the NIST Library and the identified compound is shown in Table 1.

The second peak was fragmented into 9 spectra with candidate mass $(\mathrm{m} / \mathrm{z}) 522.10,524.22,543.98,561.33,579.30,597.21,614.17$, and 619.15 as shown in Figure 2 above. The LC MS spectrums interpretation was performed using the NIST Library and the identified compound is shown in Table 1 .

The third peak was fragmented into 7 spectra with candidate mass $(\mathrm{m} / \mathrm{z})$ $575.22,596.29,611.86,626.20,628.21,613.24$, and 633.13 as shown in Figure 3 below. The LC-MS spectrums interpretation was performed using the NIST Library and the identified compound details are shown in Table I below.

\section{LC/SQ MS analysis of the ethanolic extracts of the leaves}

LC MS analysis of the ethanolic extracts of leaves of Annona muricata generated 2 peaks with the retention times of 0.60224 and $7.12391 \mathrm{~min}$ (Figures 4 and 5 respectively). Each peak was then fragmented, resulting into 10 and 7 fragmentation spectra respectively as shown in Figures 4 and 5 respectively. The LC MS spectrums interpretation was performed using the NIST Library and corresponding compounds identified. The results of spectrum interpretation on ethanolic extracts of leaves of Annona muricata indicates that there are two detected substances. The names, structures and uses have been elucidated as shown Table 2 . 


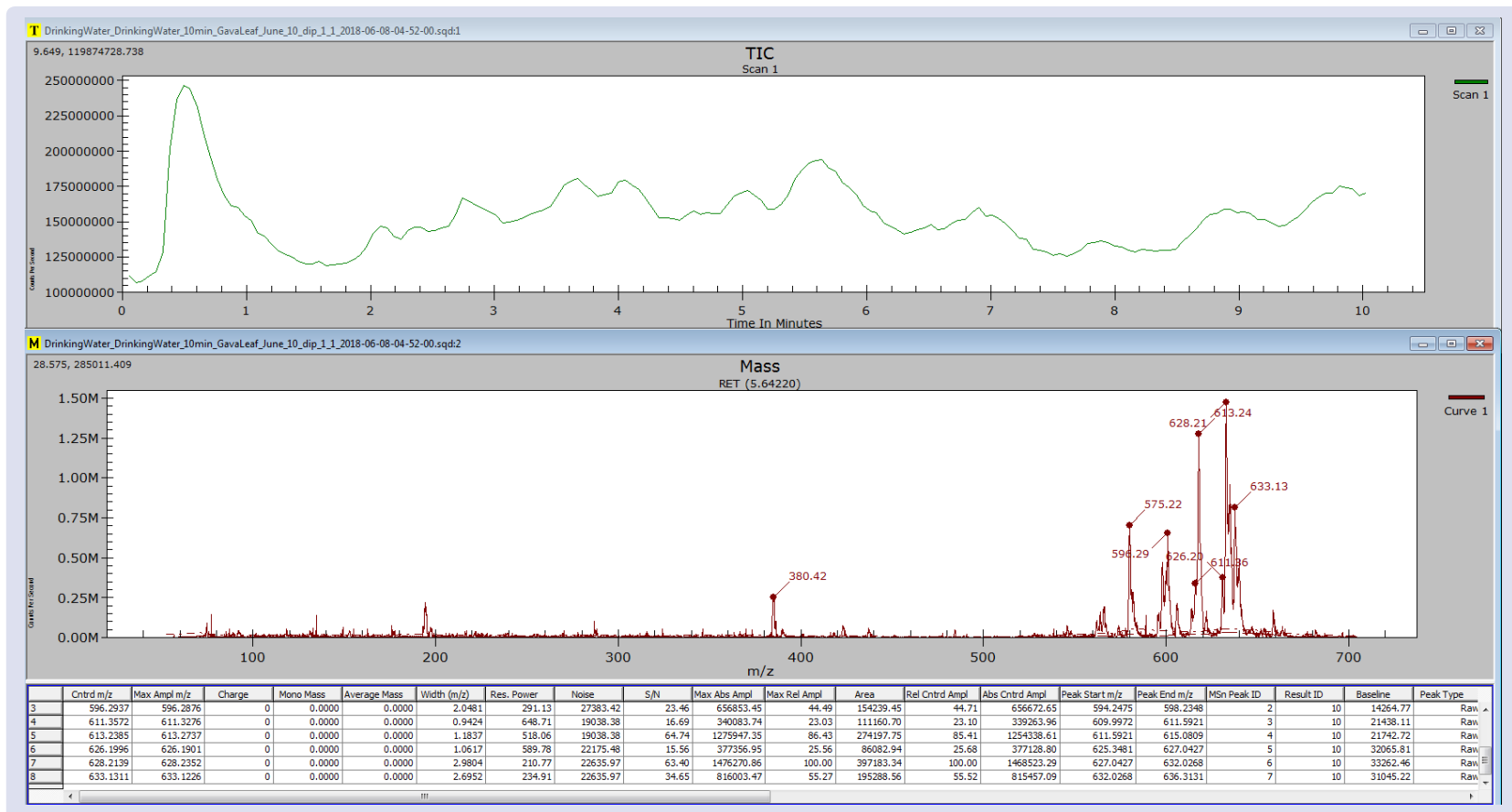

Figure 3: LC MS total ion chromatogram for EEAM- fruits at peak 3.

Table 1: Identified compounds from the peaks of fruits extracts.

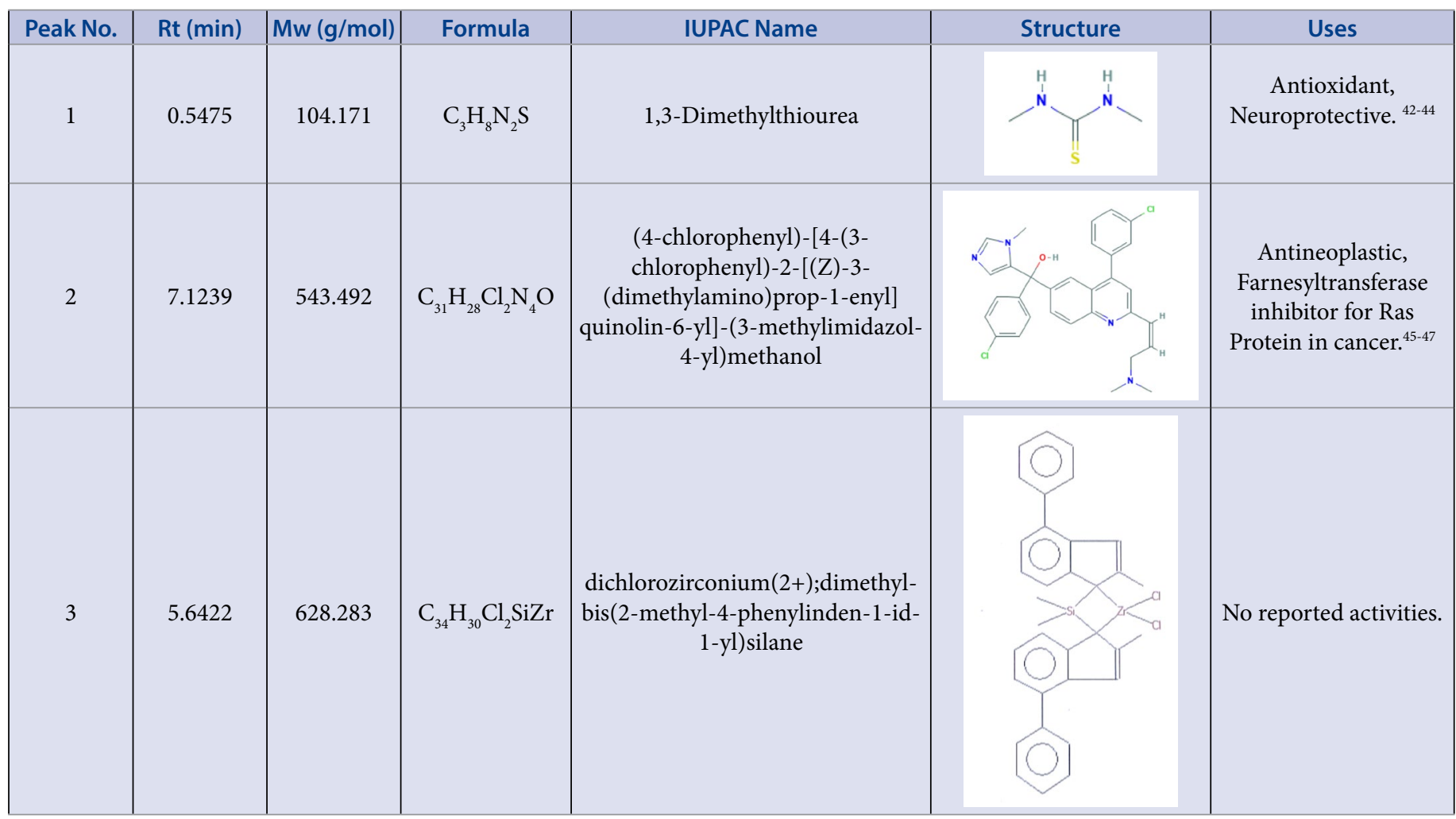

The first peak was fragmented into 10 spectra with candidate mass $(\mathrm{m} / \mathrm{z})$ $59.48,69.45,71.37,103.82,115.95,172.52,294.64,298.70,328.66$, and 340.95 as shown in Figure 4 below. The LC MS spectra interpretation was performed using the NIST Library and the identified compound is shown in Table 2.

The second peak was fragmented into 7 spectra with candidate mass $(\mathrm{m} / \mathrm{z}) 575.22,596.29,611.86,626.20,628.21,613.24$, and 633.13 as shown in Figure 5 below. The LC-MS spectrums interpretation was performed using the NIST Library and the identified compound details are shown in Table 2 below.

\section{General discussion of the LC/SQ MS results}

The LC MS analysis of ethanolic extracts of fruits of Annona muricata has revealed three novel compounds, two of which have been previously reported to have strong antioxidant and antineoplastic activities. 1,3-Dimethylthiourea has been reported to be an antioxidant as well as protective to pancreatic islets against damage by cytokines and prevention of myocardial and pulmonary reperfusion injury. ${ }^{42}$ Earlier studies have also reported the marked antioxidant activities of 1,3-Dimethylthiourea where its protective activity against retinal 


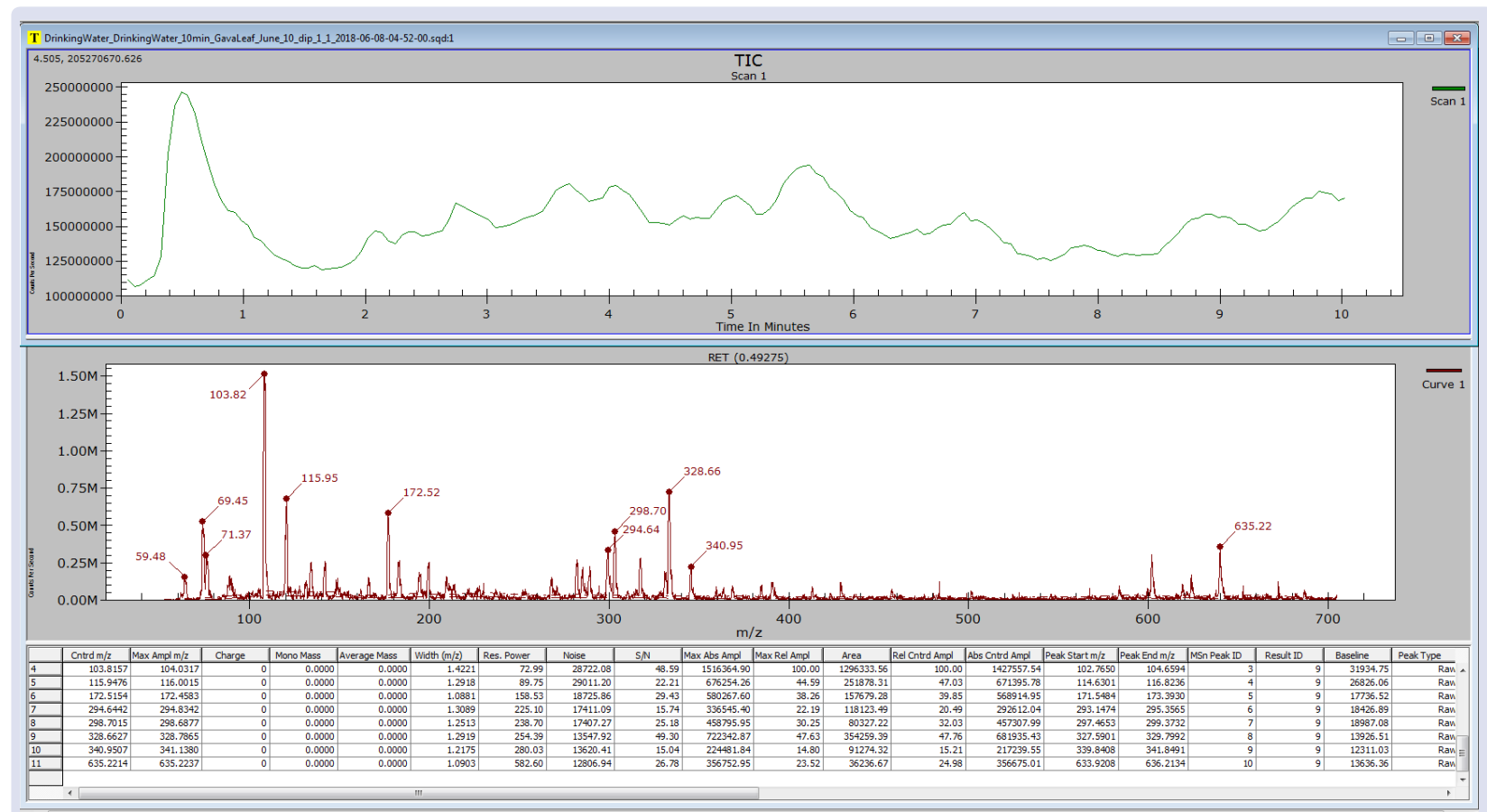

Figure 4: LC MS total ion chromatogram for EEAM- leaves at peak 1.

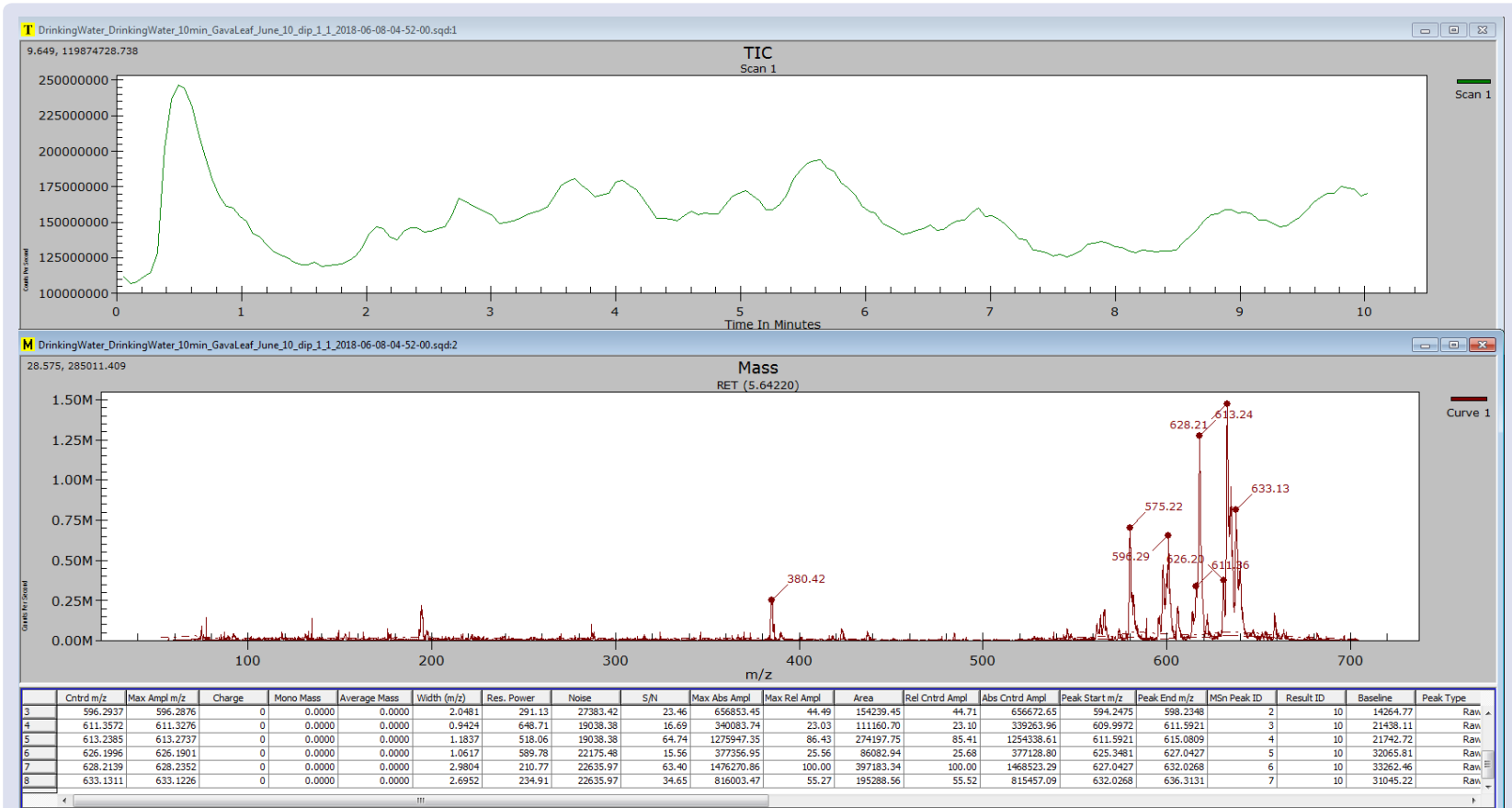

Figure 5: LC MS total ion chromatogram for EEAM- leaves at peak 2

damage by intense visible light was reported. ${ }^{43}$ In the study, intense light exposure resulted in an increase in heme oxygenase 1 (HO-1) protein and a marked decrease from the high level of HO-1 mRNA induced by light insult was observed when animals were allowed to recover in the dark for $24 \mathrm{hr}$ after light exposure. Most important, treatment of animals with 1,3-dimethylthiourea, a synthetic antioxidant, prior to light exposure effectively blocked the increase in HO-1 mRNA, thus showing the protective effect of the compound. Since increased expression of HO-1 is thought to be a cellular defense against oxidative damage, its expression may play an important role in protecting the retina against light damage. In another study, the neuroprotective effect of 1,3-dimethylthiourea was reported and it was observed that the number of affected neurons was significantly reduced after 1,3dimethylthiourea pretreatment. ${ }^{44}$ Presence of 1,3 -dimethylthiourea as a natural product in the fruit extracts of Annona muricata is a good indication of the potential this compound has to people who feed on its fruits as well as the different frontiers it can open for synthesis of more efficient and protective drugs.

On the other hand, (4-chlorophenyl)-[4-(3-chlorophenyl)-2-[(Z)-3(dimethylamino)prop-1-enyl]quinolin-6-yl]-(3-methylimidazol-4-yl) methanol, commonly known as Quinoline, has been shown to be very strong as a Farnesyltransferase inhibitor for Ras Protein in different cancer types including leukemia. ${ }^{45,46}$ It is important to note that since 
Table 2: Identified compounds from the peaks of leaves extracts.

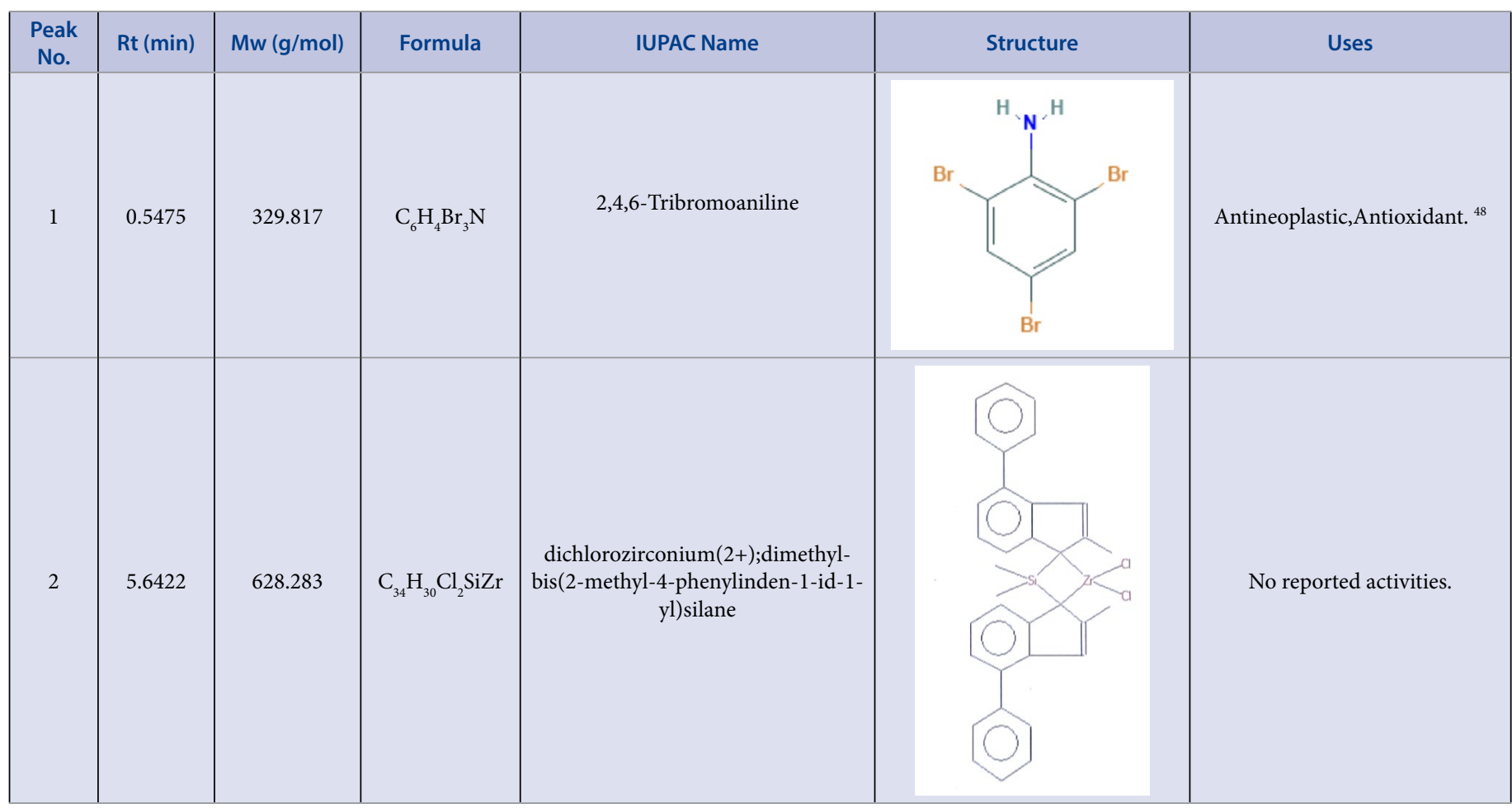

its identification, the enzyme protein farnesyltransferase (FTase) that catalyzes the first and essential step of the three Ras-processing steps has emerged as the most promising target for therapeutic intervention. FTase has therefore been implicated as a potential target in inhibiting the prenylation of a variety of proteins, thus in controlling varied disease states (e.g. cancer, neurofibromatosis, restenosis, viral hepatitis, bone resorption, parasitic infections, corneal inflammations, and diabetes) associated with prenyl modifications of Ras and other proteins. ${ }^{47}$ Furthermore, it has been suggested that FTase inhibitors indirectly help in inhibiting tumors via suppression of angiogenesis and induction of apoptosis. ${ }^{47}$ The presence of this compound which such reported activities indicate the potential uses of the fruit extracts of Annona muricata in the development of specific drugs for management conditions such as cancer.

Of the compounds identified in the leaves extracts, 2,4,6-Tribromoaniline has been widely studied because of its anticipated antineoplastic and anticancer activities, though a study showing its complete activity is yet to be reported. ${ }^{48}$ From the results above, it is evident that compound dichlorozirconium (2+); dimethylbis(2-methyl-4-phenylinden-1-id-1-yl) silane is common to both leaves and fruits. However, there has been no previously reported activities for this compound. This could be due to the fact that no studies have been undertaken to isolate and evaluate its properties. Pending further studies, we hereby propose that dichlorozirconium (2+); dimethyl-bis (2-methyl-4-phenylinden-1-id-1-yl) silane could be widely responsible for the antineoplastic and antioxidant activity of the plant extracts of Annona muricata. Its presence in both fruits and leaves of Annona muricata is an indication of how useful these parts can be in the management of such conditions. Some bioactivities previously shown for extracts from leaves and fruits of Annona muricata include antioxidant, ${ }^{33,49}$ anti-bacterial, ${ }^{50-53}$ anti-inflammatory, ${ }^{54}$ anti-viral, ${ }^{55}$ anti-diabetic, ${ }^{28}$ antineoplastic and anticancer, ${ }^{13,23,30-37}$ among others. We therefore further propose that these compounds play important roles in relation to some of the above-named bioactivities. It however needs further studies to be conducted by isolating and studying them in details for conclusive activity discovery.
This is the first study on the use of LC/SQ MS analysis which reports the presence of the above identified compounds in an extract of Annona muricata part. We can also confirm that no previous studies have reported these compounds in Annona muricata irrespective of the method of screening used and therefore these findings are a very important addition to our understanding of this plant.

\section{CONCLUSION}

The current study shows that Annona muricata contains various compounds which have been reported to have bioactivities against different conditions. Based on the LC/SQ MS analysis of ethanolic extracts of fruits and leaves of Annona muricata, it was identified that some of the compounds in the extracts under study were antioxidant and antineoplastic in nature. From these results, it can be concluded that ethanolic extracts of fruits and leaves of Annona muricata contain compounds which have been shown to have antioxidant and antineoplastic potential and can therefore be used development of drug remedies for the treatment of cancer and related conditions. This is the first report on the presence of these compounds in an Annona muricata extract. These findings notwithstanding, further studies on some of these identified compounds whose functions have not been previously reported need to be conducted to authenticate their exact properties and support our proposal that they might also be involved in the bioactivities against different conditions such as oxidative stress, diabetes and cancer among others.

\section{ACKNOWLEDGEMENT}

This study forms part of YG's PhD work in Molecular Biology and Biotechnology at the Pan African University Institute for Basic Sciences, Technology and Innovation. The authors would therefore wish to thank the Pan African University for Doctoral Scholarship as well as funding and Busitema University for the protected time given to YG to allow for the undertaking of this work. We further thank the Uganda Natural Chemotherapeutics Research Institute and Uganda Directorate of Water Resources Management (DWRM) for the support that enabled part of the work to be conducted in their respective Institutions. Last 
but not least, we thank Mr Katumba Godfrey and Mr Mubangizi Barnabas of the DWRM for their technical support in ensuring that the analysis was conducted perfectly. Finally, we thank everyone that supported the process of samples collection in the different districts of Eastern Uganda, especially Naigaga Maureen, Mukwantampola George and Gaati Joweria (Kaliro District); Naikoba Macklin and Lulenzi Jalia (Iganga District); as well as Kasajja Anthony and Kirenzi Juma (Mbale District).

\section{CONFLICTS OF INTEREST}

The authors declare that they have no conflicts of interest.

\section{ABBREVIATIONS}

LC MS: Liquid Chromatography Mass Spectrometry; MS: Mass Spectrometry; SQ: Single Quadrupole; LC/SQ MS: Liquid Chromatography Single Quadrupole Mass Spectrometry; NIST: National Institute of Standards and Technology; IUPAC: International Union for Pure and Applied Chemistry; TIC: Total Ion Chromatogram; EEAM; Ethanolic Extracts of Annona muricata

\section{REFERENCES}

1. Abou-Elella F, Hanafy EA, Gavamukulya Y. Determination of antioxidant and antiinflammatory activities, as well as in vitro cytotoxic activities of extracts of Anastatica hierochuntica (Kaff Maryam) against HeLa cell lines. J Med Plants Res. 2016;10(7):77-87.

2. Thirumal M, Kishore G, Prithika R, Das S, Nithya G. Invitro anticancer activity of tecomastans ( L.) ethanolic leaf extract on human breast cancer cell line (Mcf7). ljpcbs. 2012;2(4):488-93

3. Gavamukulya Y, Abou-Elella F, Wamunyokoli F, El-Shemy H. GC-MS analysis of bioactive phytochemicals present in ethanolic extracts of leaves of annona muricata: A further evidence for its medicinal diversity. Pharmacogn J. 2015;7(5):300-4

4. Coria-Te'llez A, Montalvo-Gonzalez E, Yahia E, Obledo-Va'Zquez E. Annona muricata: A comprehensive review on its traditional medicinal uses, phytochemicals, pharmacological activities, mechanisms of action and toxicity. Arab J Chem. 2016

5. Gavamukulya Y, Wamunyokoli F, El-Shemy HA. Annona muricata: Is the natural therapy to most disease conditions including cancer growing in our backyard? A systematic review of its research history and future prospects. Asian Pac J Trop Med. 2017;10(9):835-48.

6. Pinto A, De Q, Cordeiro M. Annona muricata. In: Williams JT, editor. Annona Species, Taxonomy and Botany Inter-national Centre Underutilised Crops. Southampton, UK: University of Southampton;2005. p. 3-16.

7. Benavides A, González A, Cisne Contreras J. Numerical characterization of guanabana (Annona muricata L.) germplasm sampling in situ in the pacific and northern nicaragua. La Calera. 2004;10(15):46-52

8. Evangelista-Lozano S, Cruz-Castillo J, Pe'rez-Gonza'lez S, Mercado-Silva E, Da'vila-Ortiz G. Production and fruit quality of guanabanos (Annona muricata L.) from Jiutepec seed, Morelos, Mexico. Chapingo Hortic Ser. 2003;9(1):69-79.

9. Orwa C, Mutua A, Kindt R. Agroforestree database: a tree species reference and selection guide version 4.0. ICRAF, Nairobi, KE 2009.

10. Badrie N, Schauss A. Soursop (Annona muricata L.): composition, nutritional value, medicinal uses, and toxicology. In: Watson $\mathrm{R}$, Preedy $\mathrm{V}$, editors. Bioactive Foods in Promoting Health. Oxford: Academic Press; 2010. p. 621-43.

11. Leatemia JA, Isman MB. Insecticidal activity of crude seed extracts of Annona spp., Lansium domesticum and Sandoricum koetjape against lepidopteran larvae. Phytoparasitica. 2004;32(1):30-7.

12. Langenberger G, Prigge V, Martin K, Belonias B, Sauerborn J. Ethnobotanical knowledge of Philippine lowland farmers and its application in agroforestry. Agrofor Syst. 2009;76(1):173-94

13. Betancur-Galvis L, Saez J, Granados H. Antitumor and antiviral activity of Colombian medicinal plant extracts. Mem Inst Oswaldo Cruz. 1999;94(4):531-5.

14. Magaña MA, Gama LM, Mariaca R. The use of medicinal plants in communities Maya-Chontales of Nacajuca, Tabasco, Mexico. Polibotánica. 2010;29:213-62.

15. DeFilipps R, Maina S, Crepin J. Medicinal plants of the Guianas (Guyana, Surinam, French Guiana). Washington, DC: Department of Botany, National Museum of Natural History, Smithsonian Institution; 2004.

16. Joyeux M, Mortier F, Fleurentin J. Screening of antiradical, antilipoperoxidant and hepatoprotective effects of nine plant extracts used in Caribbean folk medicine. Phyther Res. 1995;9(3):228-30.
17. Beyra A, Leo' n MC, Iglesias E. Ethnobotanical studies on medicinal plants in the province of Camagüey (Cuba). Ann Gard. 2004;(61):185-204.

18. Kossouoh C, Moudachirou M, Adjakidje V, Chalchat J-C, Figuérédo G. Essentia oil chemical composition of annona muricata I. leaves from benin. J Essent Oi Res. 2007;19(4):307-9.

19. Vandebroek I, Balick MJ, Ososki A. The importance of botellas and other plant mixtures in Dominican traditional medicine. J Ethnopharmacol. 2010;128(1):20 41.

20. Boyom FF, Fokou PVT, Yamthe LRT. Potent antiplasmodial extracts from Cameroonian Annonaceae. J Ethnopharmacol. 2011;134(3):717-24.

21. Nguyen-Pouplina J, Hop T, Hung T. Antimalarial and cytotoxic activities of ethnopharmacologically selected medicinal plants from South Vietnam. J Ethnopharmacol. 2007;109:417-27.

22. Ssenyange $C$, Namulindwa A, Oyik B. Plants used to manage type II diabetes mellitus in selected districts of central Uganda. Afr Health Sci. 2015;15(2):496502

23. Pieme CA, Kumar SG, Dongmo MS. Antiproliferative activity and induction of apoptosis by Annona muricata (Annonaceae) extract on human cancer cells. BMC Complement Altern Med. 2014;14(1):516.

24. Ross I. Medicinal plants of the world: chemical constituents, traditional and modern medicinal uses. Second. Humana Press; 2010.

25. Atawodi S. Nigerian foodstuffs with prostate cancer chemopreventive polyphenols. In: Infectious Agents and Cancer. 2011. p. S9.

26. Samuel A, Kalusalingam A, Chellappan D. Ethnomedical survey of plants used by the Orang Asli in Kampung Bawong, Perak, West Malaysia. J Ethnobiol Ethnomed. 2010;6(1):5.

27. Coe F. Rama midwifery in eastern Nicaragua. J Ethnopharmacol. 2008;117:136157.

28. De Souza C, Karou SD, Tchacondo T. Ethnobotanical study of medicinal plants used in the management of diabetes mellitus and hypertension in the Central Region of Togo. Pharm Biol. 2011;49(12):1286-97.

29. Hajdu Z, Hohmann J. An ethnopharmacological survey of the traditional medicine utilized in the community of Porvenir, Bajo Paraguá Indian Reservation, Bolivia. J Ethnopharmacol. 2012;139(3):838-57.

30. Monigatti M, Bussmann RW, Weckerle CS. Medicinal plant use in two Andean communities located at different altitudes in the Bolívar Province, Peru. J Ethnopharmacol. 2013;145(2):450-64.

31. Cijo George V, Naveen Kumar DR, Rajkumar V, Suresh PK, Ashok Kumar $R$. Quantitative assessment of the relative antineoplastic potential of the n-butanolic leaf extract of Annona Muricata Linn. in normal and immortalized human cell lines. Asian Pacific J Cancer Prev. 2012;13(2):699-704.

32. Dai Y, Hogan S, Schmelz EM, Ju YH, Canning C, Zhou K. Selective growth inhibition of human breast cancer cells by graviola fruit extract in vitro and in vivo involving downregulation of EGFR Expression. Nutr Cancer. 2011;63(5):795-801.

33. Gavamukulya Y, Abou-Elella F, Wamunyokoli F, El-Shemy HA. Phytochemical screening, anti-oxidant activity and in vitro anticancer potential of ethanolic and water leaves extracts of Annona muricata (Graviola). Asian Pac J Trop Med. 2014;7(Suppl 1):S355-63.

34. Valencia L, Muñoz D, Robledo S. Trypanocidal and cytotoxic activity of extracts from Colombian plants. Biomédica. 2011;31:552-9.

35. Nawwar M, Ayoub N, Hussein S, Hashim A. Flavonol triglycoside and investigation of the antioxidant and cell stimulating activities of Annona muricata Linn. Arch Pharm Res. 2012;35(5):761-7.

36. Ménan H, Banzouzi J, Hocquette A, Pélissier Y. Antiplasmodial activity and cytotoxicity of plants used in West African traditional medicine for the treatment of malaria. J Ethnopharmacol. 2006:105(1-2):131-136.

37. Moghadamtousi SZ, Rouhollahi E, Karimian $\mathrm{H}$. The chemopotential effect of annona muricata leaves against azoxymethane- induced colonic aberrant crypt foci in rats and the apoptotic effect of acetogenin annomuricin e in HT-29 cells : A bioassay- guided approach. PLoS One. 2015;10(4):1-28.

38. Moghadamtousi SZ, Fadaeinasab M, Nikzad S, Mohan G, Ali H, Kadir H. Annona muricata (Annonaceae): A review of its traditional uses, isolated acetogenins and biological activities. Int J Mol Sci. 2015;16(7):15625-58.

39. Patel S, Patel JK. A review on a miracle fruits of Annona muricata. J Pharmacogn Phytochem. 2016;5(51):137-48.

40. Liaw C-C, Wu T-Y, Chang F-R, Wu Y-C. Historic perspectives on annonaceous acetogenins from the chemical bench to preclinical trials. Planta Med. 2010;76(13):1390-404.

41. PerkinElmer. Flexar SQ 300 MS: A reference Notebook of LC/SQ MS Applications. Third Edit. Waltham, MA: PerkinElmer, Inc; 2012

42. National Center for Biotechnology Information. PubChem Compound Database; CID=2723631 [Internet]. 2005 [cited 2019 Feb 19];Available from: https://pubchem.ncbi.nlm.nih.gov/compound/2723631 
43. Chader GJ, Kutty G, Kutty RK, Wiggert B, Darrow RM, Organisciak DT. Induction of heme oxygenase 1 in the retina by intense visible light: suppression by the antioxidant dimethylthiourea. Proc Natl Acad Sci. 2006;92(4):1177-81.

44. Rajdev S, Fix AS, Sharp FR. Acute phencyclidine neurotoxicity in rat forebrain: induction of haem oxygenase- 1 and attenuation by the antioxidant dimethylthiourea. Eur J Neurosci. 1998;10(12):3840-52.

45. National Center for Biotechnology Information. CID $=58635553$ [Internet]. PubChem Compd. Database. 2012 [cited 2018 Nov 18];Available from: https:// pubchem.ncbi.nlm.nih.gov/compound/58635553

46. Venet MG, Pilatte INC, Angibaud PR. Farnesyl transferase inhibiting quinoline and quinazoline derivatives as farnesyl transferase inhibitors. 2006;1-19.

47. Ayral-Kaloustian S, Salaski E. Protein farnesyltransferase inhibitors. Curr Med Chem. 2002;9(10):1003-32

48. National Center for Biotechnology Information. PubChem Compound Database; CID=8986 [Internet]. 2005 [cited 2019 Feb 20];Available from: https://pubchem. ncbi.nlm.nih.gov/compound/8986.

49. Correa-Gordillo J, Ortiz J, Sa'nchez-Mejía M, Pacho'n H. Antioxidant activity in guanabana (Annona muricata L.): a literature review. Lat Am Caribb Bull Med Aromat Plants. 2012;11(2):111-26.
50. Viera GHF, Mourão JA, Ângelo ÂM, Costa RA, Vieira RHS dos F. Antibacterial effect (in vitro) of moringa oleifera and annona muricata against gram positive and gram negative bacteria. Rev Inst Med Trop Sao Paulo. 2010;52(3):129-32.

51. Bento E, Matias E, Brito F. Association between food and drugs: Antimicrobial and synergistic activity of annona muricata L. Int J Food Prop. 2013;16(4):73844.

52. Solomon-Wisdom G, Ugoh S, Mohammed B. Phytochemical screening and antimicrobial activities of Annona muricata (L) leaf extract. Am J Biol Chem Pharm Sci. 2014;2:1-7.

53. Chithra K, Shaji C, Binu T. Evaluation of major phytochemical constituents of two edible fruit yielding species of Annonaceae: Annona muricata L. and Annona reticulata L. J Med Plants Stud. 2016;4(44):198-202.

54. Laksmitawati D, Prasanti A, Larasinta N. Anti-inflammatory potential of gandarusa (gendarussa vulgaris nees) and soursoup (annona muricata I) extracts in LPS stimulated-macrophage cell (RAW264.7). J Nat Remedies. 2016;16(2):73-81.

55. Padma P, Pramod N, Thyagarajan S. Effect of the extract of Annona muricata and Petunia nyctaginiflora on Herpes simplex virus. J Ethnopharmacol. 1998;61:81 3.

\section{GRAPHICAL ABSTRACT}

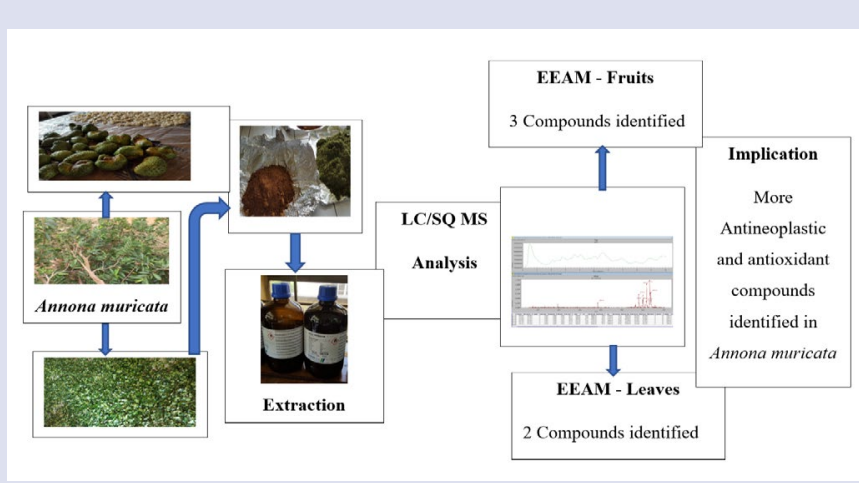

\section{SUMMARY}

- Ethanolic extracts of fruits and leaves of Annona muricata were analyzed using LC/SO MS. Three compounds were identified in the fruits extract while two compounds were identified in the leaves extract. Most of the identified compounds have been known to be strong antioxidant and antineoplastic agents. Compound dichlorozirconium(2+); dimethyl-bis(2-methyl-4phenylinden-1-id-1-yl)silane was common to both fruits and leaves.

- We report for the first time the presence of these 4 compounds in Annona muricata and further propose that even the compounds whose functions have not been previously reported could actually be involved in the different bioactivities of Annona muricata including the antineoplastic and antioxidant activities.

- The results suggest that the plant parts under study can be very important antioxidant and antineoplastic agents upon which modern natural anticancer drugs can be developed. Further studies are proposed to understand the exact functioning of these compounds.

\section{ABOUT AUTHORS}

Yahaya Gavamukulya is a Ph.D. Candidate in Molecular Biology and Biotechnology at PAUSTI and holds an MSc in Molecular Biology and Biotechnology from the same University. He obtained a BSc Degree (Biochemistry and Botany) from Makerere University. He is also a Lecturer in the department Biochemistry and Molecular Biology at the Busitema University Faculty of Health Sciences in Uganda. His research interests are in green nanotechnology and cancer treatment.

Esther N Maina earned her Ph.D. in Medical and Molecular genetics from University of Birmingham in 2004 and is currently a Senior Lecturer in the Department of Biochemistry at the University of Nairobi as well as a visiting Lecturer at PAUSTI. She has research interests in molecular mechanisms of cancer and its treatment.

Amos M Meroka is a Ph.D. Candidate in the Department of Biochemistry at the University of Nairobi. He holds an MSc in Biochemistry and is a Lecturer of Biochemistry at the Kenya Methodist University in Meru. His research interests are in medicinal plants and cancer treatment.

Edwin S Madivoli is a Ph.D. Candidate in Chemistry at University of Nairobi. He holds an MSc in Analytical Chemistry from Jomo Kenyatta University of Agriculture and Technology (JKUAT) and currently steeped in research about nanocellulose and its applications.

Hany A El-Shemy earned his two PhDs at Cairo University (Ph.D.in Biochemistry) and Hiroshima University (Ph.D. in Agriculture, Genetic Engineering), in 1996 and 2006 respectively. He is a professor of Biochemistry at the faculty of Agriculture, Cairo University and a visiting Professor at PAUSTI. 
Gabriel Magoma earned his Ph.D. in Biochemistry from JKUAT and Tea Research Foundation of Kenya in 2001 and is currently a Professor of Biochemistry and the Director PAUSTI.

Fred Wamunyokoli earned his Ph.D. from University of Cape Town, South Africa/ National Institutes of Health, United States of America in 2002 and is currently a Professor of Biochemistry at JKUAT and a visiting Professor at PAUSTI.

Cite this article: Gavamukulya Y, Maina EN, Meroka A, Madivoli ES, El-Shemy HA, Magoma G, et al. Liquid Chromatography Single Quadrupole Mass Spectrometry (LC/SO MS) Analysis Reveals Presence of Novel Antineoplastic Metabolites in Ethanolic Extracts of Fruits and Leaves of Annona muricata. Pharmacog J. 2019;11(4):660-8. 